\title{
Rosemary as natural antioxidant to prevent oxidation in chicken burgers
}

Daiane PEREIRA ${ }^{1}$, Rafaelly Simionatto PINHEIRO ${ }^{2}$, Leila Fernanda Serafini HELDT ${ }^{1}$, Cristiane de MOURA ${ }^{1}$, Mirelli BIANCHIN ${ }^{1}$, Jacqueline de Florio ALMEIDA ${ }^{3}$, Amália Soares dos REIS ${ }^{1}$, Ingridy Simone RIBEIRO ${ }^{4}$, Charles Windson Isidoro HAMINIUK ${ }^{3}$, Solange Teresinha CARPES ${ }^{1,2 *}$

\begin{abstract}
Rosemary (Rosmarinus officinalis) is known for their sensory characteristics and antioxidant properties, mainly due to the presence of several phenolic compounds. The aim of this work, was determine the antioxidant activity and apply the Rosemary lyophilized extract (RLE) in chicken burger, for assess their ability to reduce the lipid oxidation. Total antioxidant capacity and phenolic compounds profile were analyzed by colorimetric tests and liquid chromatography analysis, respectively. Thiobarbituric acid reactive substances assay was used to evaluate the ability of the RLE to prevent lipid peroxidation in chicken burger stored at $4{ }^{\circ} \mathrm{C}$. Three treatments of chicken burgers were prepared ( $\mathrm{T} 1$ - control, without addition of synthetic antioxidant BHT: butylated hydroxytoluene or RLE), T2 - with addition of BHT, and T3 - experimental, containing RLE). The high contents of total phenolic compounds (40.91 $\mathrm{mg} \mathrm{GAE} \mathrm{g}^{-1}$ : Gallic Acid Equivalent) and total flavonoids (24.26 $\mathrm{mg} \mathrm{QE} \mathrm{g}^{-1}$ : Quercetin Equivalents) were found in RLE. Rutin was the major phenolic compound identified in the RLE. The RLE showed strong antioxidant capacity and inhibited $48.29 \%$ of lipid oxidation (21 days of storage) in comparison to the control (T1), with low production of malonaldehyde, which has potential to be used in chicken burgers.
\end{abstract}

Keywords: lipid oxidation; antioxidant assays; TBARS; HPLC; Rosmarinus officinalis.

Practical Application: The replacing antioxidant synthetic for Rosemary extracts provide good alternatives to get healthy foods.

\section{Introduction}

Natural antioxidants offer alternatives approach to prevent the oxidative deterioration of foods. Such compounds found in plants have attracted considerable interest in preventing the auto-oxidation of fat and oil in foods (Fernández-Ginés et al., 2005; Mariutti et al., 2008). Antioxidant activities of herbs, spices, vegetables and other extracts has been linked to phenolic compounds, suggesting that the antioxidant action is similar to that of the synthetic additives (Asolini et al., 2006; Rêgo et al., 2011). Antioxidants act as scavengers of free radicals and oxygen, which reduce the progress of lipid peroxidation. However, it is need hinder the free radicals production at start of the reaction sequence or to interrupt the sequence at some point (Singleton et al., 1999).

Currently, efforts have increased to elucidate the effects of the natural antioxidants present in vegetables and food matrices (Rather et al., 2016; Reis et al., 2017). The bioactivity of phenolic compounds depends largely of the number of hydroxyl groups linked to the aromatic ring and their relative orientation in the molecular structure. Different assays have been used to investigate the antioxidant activity of plants extracts in several matrices such as foods, natural products and body fluids (Erkan et al., 2008; Reşat et al., 2013; Guo et al., 2016).
The Rosemary belongs to the Lamiaceae and possesses a number of desirable technological properties. Most of the data found in the literature refers to the antioxidant, antimicrobial and anti-inflammatory potential of Rosemary, which is often related to the presence of rosmarinic acid and carnasol, among other polyphenols (Erkan et al., 2008; Genena et al., 2008; Pour et al., 2014). Rosemary extracts prevent autooxidation in sunflower oil (Chen et al., 2014) and it is used as natural antioxidant to inhibit lipid oxidation in pork-based products (Lara et al., 2011; Hać-Szymańczuk et al., 2011), and other types of foods such as sausages (Georgantelis et al., 2007), and chicken nuggets (Teruel et al., 2015).

Lipid oxidation in foods is one of the main factors that affect the product quality such as, flavour, colour and texture, reducing the nutritional value. Oxidative processes in meat products are influenced by polyunsaturated fatty acids in the presence of iron, presence of prooxidants and endogenous antioxidants, action of oxygen, the addition of salt and by mechanical processes (Min \& Ahn, 2005). According to Devatkal \& Naveena (2010) lipid oxidation is a chain reaction so that polyunsaturated fatty acids react sequentially with oxygen molecules by free radical mechanism making peroxides. The addition of antioxidants in meat products are used to prolong the shelf life, increase safety 
and prevent damage caused by lipid oxidation (Devatkal \& Naveena, 2010; Chen et al., 2014).

Synthetic phenolic preservatives such as tertiary-butylhydroquinone (TBHQ), butylated hydroxyanisole (BHA), butylated hydroxytoleune (BHT), and propyl gallate (PG) are approved for use in meat processing in many countries. However, concern about the health risks associated with chronic consumption of these chemical substances are getting attention in the search for natural substances with antioxidant activity (Ibrahim et al., 2010; Shahidi \& Zhong, 2010; Rather et al., 2016).

The aim of this work was to determine the antioxidant properties and phenolic profile by liquid chromatography, and the effects of adding of Rosemary lyophilized extract (RLE) in chicken burgers, in order to avoid the lipid oxidation during cold storage at $4{ }^{\circ} \mathrm{C}$.

\section{Materials and methods}

\subsection{Chemicals}

Gallic acid, ferulic acid, caffeic acid, p-coumaric acid, trans-cinnamic acid, kaempferol, rutin, and quercetin were obtained from Sigma-Aldrich (Hamburg, Germany). DPPH (2,2-diphenyl-1-picrylhydrazyl), ABTS•+ (2,2'-azino-di(3-ethylbenzthiazoline-6-sulphonic acid), TPTZ (2,4,6-Tri(2-pyridyl)-s-triazine), trichloroacetic acid (TCA), Folin-Ciocalteu phenol reagents, Trolox, linoleic acid, $\beta$-carotene, and Tween 40 were obtained from Sigma Aldrich (Sternheim, Germany). Ethylenediaminetetraacetic acid (EDTA), thiobarbituric acid (TBA), chloroform, ethyl alcohol and methanol were purchased from Vetec (Sao Paulo, Brazil).

\subsection{Preparation of Rosemary lyophilized extract (RLE)}

The preparation and the analysis of RLE were described by Carpes et al. (2008). The Rosmarinus officinalis samples were cultivated in Pato Branco, Paraná, Brazil. The leaves were collected, dried in a air circulation oven at $35^{\circ} \mathrm{C}$ and ground in analytical mill. The leaves $(2 \mathrm{~g}$ ) were incubated with $15 \mathrm{~mL}$ of $80 \%$ ethanol (v/v), at $70{ }^{\circ} \mathrm{C}$ in water bath for $30 \mathrm{~min}$. Afterwards, the extract was filtered and stored at $-5^{\circ} \mathrm{C}$. The supernatant was lyophilized (Liotop L101, São Carlos, Brazil). The Rosemary lyophilized extract was named as RLE and used in total phenols, flavonoids, antioxidant activity, and HPLC analysis. The extraction was performed in triplicate.

\subsection{Total phenols and total flavonoids}

Total phenolic compounds were quantified by Folin-Ciocalteu method described by Singleton et al. (1999), using gallic acid as the standard. The results were expressed as $\mathrm{mg} \mathrm{GAE} \mathrm{g}^{-1}$ of sample (GAE: Gallic Acid Equivalent). The content of total flavonoids was quantified according to Carpes et al. (2008). Results were interpolated with quercetin calibration curve and presented in mg QE g-1 of sample (QE: Quercetin Equivalent).

\subsection{HPLC-DAD-UV-Vis profile}

The analysis of phenolic compounds in RLE was carried out using a Dionex Ultimate 3000 chromatograph equipped with an Acclaim ${ }^{\circledR} 120 \mathrm{C} 18$ colunn at $40{ }^{\circ} \mathrm{C}$ with a flow rate of $1.0 \mathrm{~mL} \mathrm{~min}^{-1}$ and a photodiode array detector (HPLC/PDA). The mobile phases were carried out according to Rodrigues et al. (2015) and Chromeleon software was used in this experiment. Extracts were filtered through a $0.22 \mu \mathrm{m}$ filter nylon syringe (Millipore, São Paulo, Brazil). Ferulic acid, gallic acid, p-coumaric acid, trans-cinnamic acid, kaempferol, rutin, and quercetin were examined. The assays were carried out in triplicate.

\subsection{Antioxidant capacity tests}

\section{$D P P H$ radical assay}

The DPPH free radical scavenging activity was realized according Brand-Williams et al. (1995). $0.5 \mathrm{~mL}$ of RLE $80 \mathrm{~g} / \mathrm{L}, 3.0 \mathrm{~mL}$ of ethanol and $0.3 \mathrm{~mL}$ of $0.5 \mathrm{mM}$ DPPH solution in ethanol were mixed. The absorbance was measured using a spectrophotometer (Bel Photonics 2000, Piracicaba, Brazil) at $517 \mathrm{~nm}$. The concentration required to obtain a $50 \%$ antioxidant effect value (EC50) was calculated by linear regression of graphs where the axis of the abscissas is the concentration in $\mathrm{mg} / \mathrm{mL}$ and the ordinal axis is the antioxidant activity (\%). The assays were carried out in triplicate. Standard solutions of BHT (butylated hydroxytoluene), BHA (butylated hydroxyanisole) and alfa-tocopherol were used at final concentrations of $0.1 \mathrm{mg} \mathrm{mL}^{-1}$, as positive controls.

\section{ABTS $^{\cdot+}$ scavenging activity}

The ABTS assay was performed according to Re et al. (1999). ABTS solution ( $1 \mathrm{~mL})$ was diluted with ethanol $(60 \mathrm{~mL})$ until the absorbance 0.70 at $734 \mathrm{~nm}$ in spectrophotometer (UV-VIS Bel Photonics 2000 Piracicaba, Brazil). Trolox was used as reference and the result was expressed as $\mathrm{mmol} / \mathrm{g}$ of TEAC (Trolox-equivalent antioxidant capacity). All assays were made in triplicate.

\section{Coupled oxidation of $\beta$-carotene/linoleic acid assay}

The $\beta$-carotene bleaching assay was determined according to Ahn et al. (2004). About $10 \mathrm{mg}$ of $\beta$-carotene, $40 \mathrm{mg}$ of linoleic acid and $400 \mathrm{mg}$ Tween 40 were measured, and dissolved in $100 \mathrm{~mL}$ of chloroform. An aliquot of this emulsion $(3 \mathrm{~mL})$ and $300 \mu \mathrm{L}$ of the RLE $\left(6.67 \mathrm{mg} \mathrm{mL}^{-1}\right)$ was mixed and absorbance read immediately at $470 \mathrm{~nm}$, and at 20 min intervals for 2 hours incubation at $50^{\circ} \mathrm{C}$. Antioxidant activity was presented as percent of inhibition. The BHT, BHA e a-tocopherol were evaluated in the final concentration of $0.1 \mathrm{mg} \mathrm{mL}^{-1}$ at $470 \mathrm{~nm}$. The assays were effectuated in triplicate.

\section{Ferric reducing antioxidant potential (FRAP) assay}

The FRAP assay was performed as described by Pulido et al. (2000). $25 \mathrm{~mL}$ of $0.3 \mathrm{M}$ acetate buffer, $2.5 \mathrm{~mL}$ of $10 \mathrm{mM}$ TPTZ solution, and $2.5 \mathrm{~mL}$ of $20 \mathrm{mM}$ ferric chloride were used to obtain the reagent. $3 \mathrm{~mL}$ of FRAP reagent freshly was added to $100 \mu \mathrm{L}$ of the extract and incubated in a water bath for $30 \mathrm{~min}$ at $37^{\circ} \mathrm{C}$. 
$\mathrm{FeSO}_{4} 7 \mathrm{H}_{2} \mathrm{O}$ standard curve was prepared and absorbance was measured at $595 \mathrm{~nm}$. FRAP values were expressed as $\mu \mathrm{mol} \mathrm{Fe}{ }^{2+} \mathrm{g}^{-1}$ of sample. The assays were made in triplicate.

\subsection{Preparation of the chicken burgers}

The meat used for the formulations of the chicken burgers was obtained in the city of Pato Branco - PR, Brazil. The following formulation as used: $6 \mathrm{~kg}$ of chicken meat containing $10 \%$ breast meat, $55 \%$ thigh meat and drumstick and $15 \%$ of fat from chicken skin. The meat was minced and homogenized with iced water (13.8\%), hydrated textured soy protein $(0.9 \%)$, isolated soy protein $(1 \%)$, salt $(1.4 \%)$, curing salts $(0.5 \%)$, ground white pepper $(0.2 \%)$, garlic powder $(0.1 \%)$, aroma of onion $(0.1 \%)$ and cassava starch (2\%). This basic formulation was divided into 3 lots. The first one was designated as the control without antioxidant addition (T1). The second lot was prepared by adding the BHT (butylated hydroxytoluene) at a concentration of $0.01 \%$ (T2). The third lot received Rosemary lyophilized extract at a concentration of $0.02 \%$ (T3). After the complete homogenization, the chicken burgers at a mean weight of $100 \mathrm{~g}$ were molded by hand press within the mold plate. After this, the burgers were packed in individual polyethylene plastic and stored at $4{ }^{\circ} \mathrm{C}$.

\subsection{Oxidative stability (TBARS)}

The methodology of Raharjo \& Sofos (1993) was used to evaluate oxidative stability of the chicken burgers formulations. Measurements were carried out on the day of the chicken burgers production (0) and after 7, 14 and 21 days of storage at $4{ }^{\circ} \mathrm{C}$. For evaluation of aldehydes, $5 \mathrm{~g}$ of sample in $25 \mathrm{~mL}$ of TCA diluted with EDTA were homogenized in ultra Turrax (MA-102 Marconi, Piracicaba, Brazil). After filtration, the supernatant was reacted with a solution of TBA (thiobarbituric acid) at $95^{\circ} \mathrm{C}$ for $40 \mathrm{~min}$ in water bath, forming a coloured complex. Substances reacting with thiobarbituric acid were measured spectrophotometrically at $532 \mathrm{~nm}$. TBARS levels were expressed as $\mathrm{mg}$ of malonaldehyde $\mathrm{kg}^{-1}$ sample. Lipid oxidation analysis was done in triplicate.

\section{Results and discussion}

\subsection{Total phenols, total flavonoids and preliminary chromatographic analysis}

Among the most abundant metabolites in vegetables (also known as secondary metabolites) are flavonoids and phenolic acids, which are known by antioxidant activity (Reşat et al., 2013; Dudonné et al., 2009). A positive correlation between total phenols and antioxidant activity of plant extracts has been reported (Abdel-Gawad et al., 2014). The mean value of total phenols compounds determined in ethanolic extract of Rosemary using Folin Ciocalteu method was $40.15 \pm 0.15 \mathrm{mg} \mathrm{GAE} \mathrm{g}^{-1}$ of sample and the total flavonoids content was $22.43 \mathrm{mg} \mathrm{QE} \mathrm{g}^{-1}$ of Rosemary.

The results of this study differ from those of Zheng and Wang (2001), where 39 aromatic plants from China were evaluated; among them, the Rosemary was extracted with $15 \mathrm{~mL}$ of $75 \mathrm{mM}$ phosphate buffer ( $\mathrm{pH} 7.0)$ and it was found $2.19 \pm 0.15 \mathrm{mg}$ of GAE g-1 of dry matter. Afonso et al. (2013) evaluated the inhibition of oxidative stress in cells of mice fed with hypercholesterolemic diet enriched with aqueous extract of Rosemary and reported $16.67 \pm 0.40 \mathrm{mg} \mathrm{GAE} \mathrm{g}^{-1}$ of Rosemary.

Mata et al. (2007), obtained values for the phenolic compounds in aqueous and ethanolic extracts of Rosemary varying from 58.4 to $73.5 \mathrm{mg}$ of $\mathrm{GAE} \mathrm{g}^{-1}$, respectively. Justo et al. (2008) studying ethanolic extracts of Rosemary, obtained by supercritical extraction, found values from 55 to $65 \mathrm{mg} \mathrm{GAE} \mathrm{g}^{-1}$ (dry matter). These differences are probably due to differences in growth conditions. It is known that environmental differences (geographical and climatic) agronomical practices and post-harvest conditions have effect on the concentration of total phenols (Scalzo et al., 2005; Hernanz et al., 2007; Correia et al., 2016).

In this study, three flavonoids (kaempferol, rutin, quercetin) and four phenolic acids (gallic acid, p-coumaric acid, p-cinnamic acid, ferulic acid) were identified and quantified by liquid chromatography (Table 1). Among the individuals phenols identified, the rutin showed the higher concentration (33.06 $\left.\pm 0.5 \mathrm{mg} 100 \mathrm{~g}^{-1}\right)$. In addition, these substances when present in natural extracts added in food products, such as meat derived-products, are allegedly responsible to avoid the lipid oxidation (Reis et al., 2017).

Table 1. Phenolic compounds identified by HPLC in RLE.

\begin{tabular}{|c|c|c|c|}
\hline Phenolic compounds & Wave length (nm) & Retention time (min) & Concentration $\left({\left.\mathrm{mg} 100 \mathrm{~g}^{-1}\right)}^{-1}\right.$ \\
\hline Gallic acid & 280 & 6.77 & $4.04^{\mathrm{d}} \pm 0.1$ \\
\hline Catechin & 280 & 10.37 & $12.55^{\mathrm{b}} \pm 0.3$ \\
\hline$p$-coumaric acid & 320 & 18.60 & $3.02^{\mathrm{e}} \pm 0.2$ \\
\hline$p$-cinnamic acid & 280 & 18.69 & $1.29^{\mathrm{g}} \pm 0.1$ \\
\hline Ferulic acid & 320 & 20.01 & $4.07^{\mathrm{d}} \pm 0.2$ \\
\hline Rutin & 370 & 25.14 & $33.06^{\mathrm{a}} \pm 0.5$ \\
\hline Quercetin & 370 & 33.52 & $10.17^{c} \pm 0.3$ \\
\hline Kaempferol & 370 & 36.84 & $1.52^{\mathrm{f}} \pm 0.2$ \\
\hline
\end{tabular}

Values mean \pm standard deviation; RLE: Rosemary lyophilized extract; Means followed by the same letters in the same column are not statistically different from each other, by Tukey test $(\mathrm{p}<0.05)$. 
Wojdylo et al. (2007) analysed 32 species of aromatic herbs from Poland, five of them from the family Labiatae; they analysed the phenolic profile of Rosemary extracts and the results support the findings of this study. According to authors Pérez-Fons et al. (2010) and Wojdylo et al. (2007) the antioxidant activity of ethanolic extracts of Rosemary is mainly due to phenolic compounds (phenolic acids and flavonoids).

\subsection{Antioxidant activities}

The antioxidant capacity of RLE determined by distinct in-vitro methods as DPPH, ABTS, FRAP and $\beta$-carotene/linoleic acid (Table 2). Ethanolic extract of Rosemary had lower antioxidant activities than the commercial antioxidants by the DPPH method $\left(\mathrm{EC}_{50}=127.33 \pm 0.12 \mu \mathrm{g} / \mathrm{mL}\right)$ and by the method of scavenging of the radical $\mathrm{ABTS}^{\cdot+}\left(203.11 \pm 1.10 \mu \mathrm{mol} \mathrm{g}{ }^{-1}\right.$ of Trolox $)$. Alpha-tocopherol showed the highest antioxidant activity in the $\mathrm{DPPH}^{\bullet}$ and $\mathrm{ABTS}^{\bullet+}$ tests.

The $\mathrm{EC}_{50}$ values of RLE were very low $(127.33 \mu \mathrm{g} / \mathrm{mL})$, indicating a high antioxidant activity in Rosemary (Table 2). Erkan et al. (2008) that reported a $\mathrm{EC}_{50}$ value of $54.0 \mu \mathrm{g} \mathrm{mL}^{-1}$ in Rosemary methanolic extracts using a Soxhlet apparatus, i.e, a lower than those found in this study (Table 2). Rodríguez-Rojo et al. (2012) studied Rosemary leaves collected in Spain (DPPH) and obtained values of $\mathrm{EC}_{50}$ of 45 and $17 \mu \mathrm{g} \mathrm{mL}^{-1}$ for ethanolic and aqueous extraction, respectively. It is suggested that the choice of solvent must be primarily related to the use of the extract; in the case of an aqueous extract of Rosemary, which is rich in rosmarinic acid, would be effective as an antioxidant in hydrophilic systems, while in lipophilic systems, ethanolic extracts would be more appropriate, owing to their higher content of carnosic acid. This refers that physiochemical nature of the phenolic compounds in the extracts may be more important for the antioxidant activity than the total phenols.

Justo et al. (2008) investigated the antioxidant properties of ethanolic extracts of Rosemary by the $\mathrm{DPPH} \cdot\left(\mathrm{EC}_{50}\right)$ and $\mathrm{ABTS}^{\cdot+}$ methods, and found values of $\mathrm{EC}_{50}$ varying from 120 to $9 \mu \mathrm{g} \mathrm{mL}^{-1}$ and values of $190.96 \pm 13.35 \mu \mathrm{M}$ of Trolox $\mathrm{g}^{-1}$ to $231.51 \pm 11.90 \mu \mathrm{M}$ of Trolox $\mathrm{g}^{-1}$ by $\mathrm{ABTS}^{\bullet+}$ method.

The $\beta$-carotene is oxidized during $\beta$-carotene bleaching assay, and as result of this, smaller molecules are broken, the system loses its color (Carpes et al., 2008) and the yellowish discolouration of the $\beta$-carotene can be measured spectrophotometrically. Rosemary lyophilized extract showed $92.31 \%$ of inhibition by the $\beta$-carotene method (extract concentration of $6.67 \mathrm{mg} \mathrm{g}^{-1}$ ). When comparing the results of the RLE with the positive controls
(BHA, BHT and alpha-tocopherol) by Tukey test, it can be seen that the RLE showed the lowest antioxidant capacity (Table 2). On the other hand, in the FRAP method, the RLE presented an antioxidant activity of $347.70 \pm 0.69 \mu \mathrm{mol} \mathrm{Fe} \mathrm{Fe}^{+2} \mathrm{~g}^{-1}$, while the commercial antioxidants (BHA and BHT) showed higher values. This difference can be explained by the purity of the commercial additives, differing from the complexity of the studied RLE. In addition, consumers have increasingly preferred products containing natural additives because of concerns about adverse health effects of synthetic antioxidant such as BHT and BHA (Rather et al., 2016; Reis et al., 2017). These results of the antioxidant assays clearly indicate that Rosemary extract have strong antioxidant capacity and can be used as natural antioxidant to preserve foods (Justo et al., 2008; Guo et al., 2016).

\subsection{Effect of Rosemary lyophilized extract on oxidative stability in chicken burgers}

The oxidative degradation of lipids is one of the main reactions that occur in food products and can be inhibited by the use of preservatives in meat and meat products (Georgantelis et al., 2007; Guyon et al., 2016). Lipids are subject to a series of reactions which may lead to change in their structure and can affect the nutritional quality of the food products (Shahidi \& Zhong, 2010).

TBARS test (thiobarbituric acid reactive substances) evaluates the quality of food product and is the most appropriate test for evaluating rancidity due to its simplicity and efficiency (Raharjo \& Sofos, 1993). In the meat products the TBARS test is important during meat preparation (grinding and mixing) and cooking, which favour the formation of malonaldehyde, a by-product of the decomposition of hydroperoxides formed during the oxidation process (Selani et al., 2011). The results obtained in the evaluation of lipid oxidation by TBARS in the three treatments are shown in Table 3.

On the day of processing, there was no significant difference among control (T1) and the burgers containing synthetic antioxidant (T2) or RLE (T3) ( $\mathrm{p}>0.05)$. After seven days, the samples treated with BHT and RLE showed lower concentrations of malonaldehyde in comparison with the control (Table 3 ).

It was possible to show that the levels of malonaldehyde increased over 7 days of storage in all cases; however, from 14 days, the TBARS values declined with storage time. According to Ninan et al. (2008) the decrease is probably due to the interaction of lipid oxidized products (as malonaldehyde) with proteins. However, as reviewed by Angelini (2010), another possibility for decrease of the TBARS values can be explained by the

Table 2. Antioxidant activity in RLE and commercial antioxidants.

\begin{tabular}{ccccc}
\hline Samples & DPPH $(\mu \mathrm{g} / \mathrm{mL}) \mathrm{EC}_{50}$ & $\beta$-carotene/linoleic acid $(\%)$ & ABTS $\mu \mathrm{mol} / \mathrm{g}$ de Trolox & FRAP $\left(\mu \mathrm{mol} \mathrm{Fe}{ }^{+2} / \mathrm{g}\right)$ \\
\hline RLE & $127.33^{\mathrm{a}} \pm 0.12$ & $92.31^{\mathrm{a}} \pm 0.46^{*}$ & $203.11^{\mathrm{c}} \pm 1.10$ & $347.70^{\mathrm{d}} \pm 0.69$ \\
BHT & $114.66^{\mathrm{b}} \pm 0.07$ & $63.68^{\mathrm{d}} \pm 0.18^{* *}$ & $3806.77^{\mathrm{b}} \pm 73.53$ & $2310.11^{\mathrm{b}} \pm 70.59$ \\
BHA & $72.25^{\mathrm{c}} \pm 0.07$ & $68.06^{\mathrm{c}} \pm 0.22^{* *}$ & $4743.04^{\mathrm{a}} \pm 66.37$ & $2717.79^{\mathrm{a}} \pm 171.46$ \\
Alpha-tocopherol & $61.22^{\mathrm{d}} \pm 0.06$ & $70.29^{\mathrm{b}} \pm 0.17^{* *}$ & $4775.75^{\mathrm{a}} \pm 90.27$ & $1328.80^{\mathrm{c}} \pm 22.09$ \\
\hline
\end{tabular}

RLE: Rosemary lyophilized extract; BHT: butylated hydroxytoluene; BHA: butylated hydroxyanisole EC $_{50}$ : minimum concentration necessary to inhibit the concentration of DPPH by $50 \%$; ${ }^{*}$ Concentration used $6.67 \mathrm{mg} / \mathrm{mL}^{-1}$; ${ }^{*}$ Concentration used $0.1 \mathrm{mg} / \mathrm{mL}^{-1}$; Mean \pm standard deviation; Means followed by the same letters in the same column are not statistically different from each other, by Tukey test $(\mathrm{p}<0.05)$. 
Table 3. Average of TBARS (mg of malonaldehyde $\mathrm{Kg}^{-1}$ of sample) values in chicken burgers.

\begin{tabular}{ccccc}
\hline \multirow{2}{*}{ Treatments } & \multicolumn{5}{c}{ Days of storage } \\
\cline { 2 - 5 } & 0 & 7 & 14 & 21 \\
\hline T1 & $2.09^{\mathrm{cA}} \pm 0.16$ & $2.23^{\mathrm{bA}} \pm 0.03$ & $1.89^{\mathrm{dA}} \pm 0.23$ & $2.92^{\mathrm{aA}} \pm 0.17$ \\
T2 & $2.07^{\mathrm{bA}} \pm 0.04$ & $2.14^{\mathrm{aB}} \pm 0.07$ & $1.86^{\mathrm{CB}} \pm 0.03$ & $1.544^{\mathrm{dB}} \pm 0.06$ \\
T3 & $2.08^{\mathrm{bA}} \pm 0.16$ & $2.16^{\mathrm{aB}} \pm 0.02$ & $1.83^{\mathrm{cC}} \pm 0.02$ & $1.51^{\mathrm{dC}} \pm 0.06$ \\
\hline
\end{tabular}

T1: Control- without antioxidant; T2: commercial antioxidant- BHT (butylated hydroxytoluene); T3: Rosemary lyophilized extract. Mean \pm standard deviation. Means followed by the same lower-case letters in the same row are not statistically different from each other, by Tukey test ( $\mathrm{p}<0.05)$. Means followed by the same capital letters in the same column are not statistically different from each other, by Tukey test $(\mathrm{p}<0.05)$.

Table 4. Percent decrease in TBARS values in chicken burgers treated with/without antioxidants and stored at $4{ }^{\circ} \mathrm{C}$ for 21 days.

\begin{tabular}{ccccc}
\hline \multirow{2}{*}{ Treatment } & \multicolumn{5}{c}{ Percent decrease in TBARS compared to control (T1) } \\
\cline { 2 - 5 } & 0 & 7 & 14 & 21 \\
\hline T2 & 0.96 & 3.6 & 3.59 & 47.26 \\
T3 & 0.48 & 2.7 & 3.17 & 48.29 \\
\hline
\end{tabular}

${ }^{\star}$ Data not statistically analysed, but percentages were computed from the statistical data in Table 3. T1: Control- without antioxidant; T2- commercial antioxidant - BHT (butylated hydroxytoluene); T3- Rosemary lyophilized extract.

oxidation products formed not be detected by this methodology. At 21 days, the chicken burgers without antioxidants (T1) had the highest content of malonaldehyde and there was significant difference $(\mathrm{p}<0.05)$ between the burgers containing BHT and those containing RLE (Table 3 ).

Estévez et al. (2007) found $0.1 \%$ sage essential oil was more effective in inhibiting the generation of malonaldehyde in liver pâté during 90 days at $4{ }^{\circ} \mathrm{C}$ than $0.02 \%$ BHT. Also, the addition of $0.05,0.10$ and $0.15 \%$ of Salvia officinalis in Chinese sausage had lower TBARS values compared to controls (Zhang et al., 2013). According to Brannan (2008), the oxidative rancidity occurs during frozen storage of beef and chicken. The microbiological and enzymatic reactions can be inhibited by low freezing temperatures however, the lipid oxidation continues in a reduced rate.

According to Al-Kahtani et al. (1996) and Selani et al. (2011) meat products are considered in a good state for consumption if they have values of below $3 \mathrm{mg}$ of malonaldehyde $\mathrm{kg}^{-1}$. According to these findings, the sausage containing RLE would be considered in good condition after 21 days of storage (1.51 mg malonaldehyde/kg sample) (Table 3). Therefore, the concentrations of RLE used in chicken burger were sufficient to maintain oxidative stability.

When compared to the control after 21 days of storage, the presence of BHT showed a reduction in TBARS values of $47.26 \%$. At the end of storage time (21 days), the chicken burger containing RLE inhibited $48.29 \%$ of lipid oxidation in comparison to the control chicken burger (Table 4). This demonstrates the effectiveness of the Rosemary as antioxidant to prevent lipid oxidation in chicken burger during storage.

Teruel et al. (2015) studied the bioactive compounds from Rosmarinus officinalis in chicken nuggets during nine months of the storage at $-18^{\circ} \mathrm{C}$, and found TBARS values of 4.07 to $5.88 \mathrm{mg}$ malonaldehyde $/ \mathrm{kg}$ sample. The effects of using natural herb extracts in inhibiting lipid oxidation were also reported by Ibrahim et al. (2010) who analysed burgers containing extracts of jojoba, jatropha, ginseng and ginger. The extracts showed lower TBARS values than the control, inhibiting lipid oxidation during storage, at where lowest value of TBARS was found in burgers with the addition of ginseng extract.

\section{Conclusion}

This study confirms that RLE had strong anti-oxidative effects in chicken burgers, probably due to high antioxidant activity of the phenolic compounds such as acid gallic, catechin, p-coumaric acid, ferulic acid, p-cinnamic acid, rutin, quercetin, and kaempferol. The high capacity antioxidant of these compounds, combined with storage in a refrigerated temperature, the RLE has potential to be used in chicken burgers. Finding natural antioxidant equivalent or better than commercial antioxidants is an important challenge for food technology, principally due to the adverse health effects caused by synthetic antioxidants. Thus, the RLE provide good alternatives for consumer demand for healthy meat products.

\section{Acknowledgements}

The authors thank the National Council for Scientific and Technological Development (Process Number 481758/2012-7) for financial support and the Araucaria Foundation for the scholarships.

\section{References}

Abdel-Gawad, M., El-Sayed, M., El-Wakil, E., \& Abdel-Lateef, E. (2014). In vitro antioxidant, total phenolic and flavonoid contents of six allium species growing in Egypt. Journal of Microbiology, Biotechnology and Food Science, 3(4), 343-346.

Afonso, M. S., Silva, A. M. O., Carvalho, E. B., Rivelli, D. P., Barros, S. B., Rogero, M. M., Lottenberg, A. M., Torres, R. P., \& ManciniFilho, J. (2013). Phenolic compounds from Rosemary (Rosmarinus officinalis $L$.) attenuate oxidative stress and reduce blood cholesterol concentrations in diet-induced hypercholesterolemic rats. Nutrition \& Metabolism, 10(1), 19. PMid:23374457. http://dx.doi. org/10.1186/1743-7075-10-19.

Ahn, M. R., Kumazawa, S., Hamasaka, T., Bang, K.-S., \& Nakayama, T. (2004). Antioxidant activity and constituents of propolis collected in 
various areas of Korea. Journal of Agricultural and Food Chemistry, 52(24), 7286-7292. PMid:15563208. http://dx.doi.org/10.1021/ jf048726s.

Al-Kahtani, H. A., Abu-Tarboush, H. M., Bajaber, A. S., Atia, M., Abou-Arab, A. A., \& El-Mojaddidi, M. A. (1996). Chemical changes after irradiation and post-irradiation storage in tilapia and Spanish mackerel. Journal of Food Science, 61(4), 729-733. http://dx.doi. org/10.1111/j.1365-2621.1996.tb12191.x.

Angelini, M. F. C. (2010). Desenvolvimento do produto de conveniência Quenelle de tilápia (Oreochromis niloticus) (Master's dissertation). Escola Superior de Agricultura "Luiz de Queiroz", Universidade de São Paulo, Piracicaba, 2010.

Asolini, F. C., Tedesco, A. M., Carpes, S. T., Ferraz, C., \& Alencar, S. M. (2006). Antioxidant and antibacterial activities of phenolic compounds from extracts of plants used as tea. Brazilian Journal of Food Technology, 9(3), 209-215.

Brand-Williams, W., Cuvelier, M. E., \& Berset, C. (1995). Use of a free radical method to evaluate antioxidant activity. LebensmittelWissenschaft + Technologie, 28(1), 25-30. http://dx.doi.org/10.1016/ S0023-6438(95)80008-5.

Brannan, R. G. (2008). Effect of grape seed extract on physicochemical properties of ground, salted, chicken thigh meat during refrigerated storage at different relative humidity levels. Journal of Food Science, 73(1), C36-C40. PMid:18211347. http://dx.doi.org/10.1111/j.17503841.2007.00588.x.

Carpes, S. T., Prado, A., Moreno, I. A. M., Mourão, G. B., Alencar, S. M., \& Masson, M. L. (2008). Screening of the antioxidant potential of bee pollen produced in the southern region of Brazil. Química Nova, 31(7), 1660-1664. http://dx.doi.org/10.1590/S0100-40422008000700011.

Chen, X., Zhang, Y., Zu, Y., Yang, L., Lu, Q., \& Wang, W. (2014). Antioxidant effects of Rosemary extracts on sunflower oil compared with synthetic antioxidants. International Journal of Food Science \& Technology, 49(2), 385-391. http://dx.doi.org/10.1111/ijfs.12311.

Correia, S., Gonçalves, B., Aires, A., Silva, A., Ferreira, L., Carvalho, R., Fernandes, H., Freitas, C., Carnide, V., \& Silva, A. P. (2016). Effect of harvest year and altitud on nutritional and biometric characteristics of blueberry cultivars. Journal of Chemistry, 1(1), 1-12. http://dx.doi. org/10.1155/2016/8648609.

Devatkal, S. K., \& Naveena, B. M. (2010). Effect of salt, kinnow and pomegranate fruit by-product powders on color and oxidative stability of raw ground goat meat during refrigerated storage. Meat Science, 85(2), 306-311. PMid:20374904. http://dx.doi.org/10.1016/j. meatsci.2010.01.019.

Dudonné, S., Vitrac, X., Coutière, P., Woillez, M., \& Mérillon, J.-M. (2009). Comparative study of antioxidant properties and total phenolic content of 30 plant extracts of industrial interest using DPPH, ABTS $^{*+}$, FRAP, SOD, and ORAC assays. Journal of Agricultural and Food Chemistry, 57(5), 1768-1774. PMid:19199445. http://dx.doi. org/10.1021/jf803011r.

Erkan, N., Ayranci, G., \& Ayranci, E. (2008). Antioxidant activities of Rosemary (Rosmarinus officinalis L.) extract, black seed (Nigella sativa L.) essential oil, carnosic acid, rosmarinic acid and sesamol. Food Chemistry, 110(1), 76-82. PMid:26050168. http://dx.doi. org/10.1016/j.foodchem.2008.01.058.

Estévez, M., Ramírez, R., Ventanas, S., \& Cava, R. (2007). Sage and Rosemary essential oils versus BHT for the inhibition of lipid oxidative reactions in liver pâté. Food Science and Technology, 40(1), 58-65.

Fernández-Ginés, J. M., Fernández-López, J., Sayas-Barberá, E., \& Pérez-Alvarez, J. A. (2005). Meat products as functional foods: a review. Journal of Food Science, 70(2), R37-R43. http://dx.doi. org/10.1111/j.1365-2621.2005.tb07110.x.
Genena, A. K., Hense, H., Smania, A. Jr, \& Souza, S. M. (2008). Rosemary (Rosmarinus officinalis): composition study, antioxidant and antimicrobial activities of extracts obtained with supercritical carbon dioxide. Food Science and Technology, 28(2), 463-469. http:// dx.doi.org/10.1590/S0101-20612008000200030.

Georgantelis, D., Ambrosiadis, I., Katikou, P., Blekas, G., \& Georgakis, S. A. (2007). Effect of Rosemary extract, chitosan and $\alpha$-tocopherol on microbiological parameters and lipid oxidation of fresh pork sausages stored at $4{ }^{\circ} \mathrm{C}$. Meat Science, 76(1), 172-181. PMid:22064204. http://dx.doi.org/10.1016/j.meatsci.2006.10.026.

Guo, Q., Gao, S., Sun, Y., Gao, Y., Wang, X., \& Zhang, Z. (2016). Antioxidant efficacy of Rosemary ethanol extract in palm oil during frying and accelerated storage. Industrial Crops and Products, 94(1), 82-88. http://dx.doi.org/10.1016/j.indcrop.2016.08.032.

Guyon, C., Meynier, A., \& De Lamballerie, M. (2016). Protein and lipid oxidation in meat: a review with emphasis on high-pressure treatments. Trends in Food Science \& Technology, 50(1), 131-143. http://dx.doi.org/10.1016/j.tifs.2016.01.026.

Hać-Szymańczuk, E., Lipińska, E., \& Stasiuk, M. (2011). The effect of Rosemary preparations on the microbial quality and TBARS value of model pork batters. Acta Science Polonorum: Technologia Alimentaria, 10(2), 165-174.

Hernanz, D., Recamales, A. F., Meléndez-Martínez, A. J., Gonzalezmiret, M. L., \& Heredia, F. J. (2007). Assessment of the differences in the phenolic composition of five strawberry cultivars (Fragaria $\mathrm{x}$ ananassa Duch.) grown in two different soilless systems. Journal of Agricultural and Food Chemistry, 55(5), 1846-1852. PMid:17279770. http://dx.doi.org/10.1021/jf063189s.

Ibrahim, H. M., Abou-Arab, A. A., \& Abu Salem, F. M. (2010). Addition of some natural plant extracts and their effects on lamb patties quality. Journal of Food Technology, 8(3), 134-142. http://dx.doi. org/10.3923/jftech.2010.134.142.

Justo, O. R., Moraes, Â. M., Barreto, G. P. M., Mercadante, A. Z., \& Rosa, P. T. V. (2008). Evaluation of the antioxidant potential of plant extracts obtained by supercritical fluid extraction. Nature Chemistry, 31(7), 1699-1705.

Lara, M. S., Gutierrez, J. I., Timón, M., \& Andrés, A. I. (2011). Evaluation of two natural extract (Rosemarinus officinalis L. and Melissa officinales L.) as antioxidants in cooked pork patties packed in MAP. Meat Science, 88(3), 481-488. PMid:21345605. http://dx.doi. org/10.1016/j.meatsci.2011.01.030.

Mariutti, L. R. B., Orlien, V., Bragagnolo, N., \& Skibsted, L. H. (2008). Effect of sage and garlic on lipid oxidation in high-pressure processed chicken meat. European Food Research and Technology, 227(2), 337344. http://dx.doi.org/10.1007/s00217-007-0726-5.

Mata, A. T., Proença, C., Ferreira, A. R., Serralheiro, M. L. M., Nogueira, J. M. F., \& Araújo, M. E. M. (2007). Antioxidant and antiacetylcholinesterase activities of five plants used as Portuguese food species. Food Chemistry, 103(3), 778-786. http://dx.doi. org/10.1016/j.foodchem.2006.09.017.

Min, B., \& Ahn, D. U. (2005). Mechanism of lipid peroxidation in meat and meat products: a review. Food Science and Biotechnology, 14(1), 152-153.

Ninan, G., Bindu, J., \& Joseph, J. (2008). Frozen storage studies of mince based products developes from tilapia (Oreochromis mossambicus, Peter 1852). Fishery Technology, 45(1), 35-42.

Pérez-Fons, L., Garzón, M. T., \& Micol, V. (2010). Relationship between the antioxidant capacity and effect of Rosemary (Rosmarinus officinalis L.) polyphenols on membrane phospholipid order. Journal of Agricultural and Food Chemistry, 58(1), 161-171. PMid:19924866. http://dx.doi.org/10.1021/jf9026487. 
Pour, A. R., Mirzargar, S. S., Soltani, M., Mousavi, H. A. E., \& Seyed, A. M. (2014). The antibacterial effects of Cuminum cyminum L. and Rosmarinus officinalis extracts and essential oil against Lactococcus garvieae in laboratory conditions on rainbow trout. European Journal of Experimental Biology, 4(1), 456-463.

Pulido, R., Bravo, L., \& Saura-Calixto, F. (2000). Antioxidant activity of dietary polyphenols as determined by a modified ferric reducing/ antioxidant power assay. Journal of Agricultural and Food Chemistry, 48(8), 3396-3402. PMid:10956123. http://dx.doi.org/10.1021/jf9913458.

Raharjo, S., \& Sofos, J. N. (1993). Methodology for measuring malonaldehyde as a product of lipid peroxidation in muscle tissues: A review. Meat Science, 35(2), 145-169. PMid:22061027. http:// dx.doi.org/10.1016/0309-1740(93)90046-K.

Rather, S. A., Masoodi, F. A., Akhter, R., Rather, J. A., \& Shiekh, K. A. (2016). Advances in use of natural antioxidants as food additives for improving the oxidative stability of meat products. Madridge Journal of Food Technology, 1(1), 10-17.

Re, R., Pellegrini, N., Proteggente, A., Pannala, A., Yang, M., \& RiceEvans, C. (1999). Antioxidant activity applying an improved ABTS ${ }^{\bullet+}$ radical cation decolorization assay. Free Radical Biology \& Medicine, 26(9-10), 1231-1237. PMid:10381194. http://dx.doi.org/10.1016/ S0891-5849(98)00315-3.

Rêgo, N. O. Jr., Fernandez, L. G., Castro, R. D., Silva, L. C., Gualberto, S. A., Pereira, M. L. A., \& Silva, M. V. (2011). Bioactive compounds and antioxidant activity of crude extracts of caatinga plant species. Brazilian Journal of Food Technology, 14(1), 50-57.

Reis, A. S., Diedrich, C., Moura, C., Pereira, D., Almeida, J. F., Silva, L. D., Plata Oviedo, M. S. V., Tavares, R. A. W., \& Carpes, S. T. (2017). Physico-chemical characteristics of microencapsulated propolis co-product extract and its effect on storage stability of burger meat during storage at $-15^{\circ} \mathrm{C}$. Food Science and Technology, 76, 306-313.

Reşat, A., Shela, G., Volker, B., Karen, M. S., Mustafa, O., \& Kubilay, G. (2013). Methods of measurement and evaluation of natural antioxidant capacity activity (IUPAC Technical Report). Pure and Applied Chemistry, 85(5), 957-998.

Rodrigues, C. V., Silva, M. V., Santos, A. R., Zielinski, A. A. F., \& Haminiuk, C. W. I. (2015). Evaluation of hot and cold extraction of bioactive compounds in teas. International Journal of Food Science \& Technology, 50(9), 2038-2045. http://dx.doi.org/10.1111/ijfs.12858.
Rodríguez-Rojo, S., Visentin, A., Maestri, D., \& Cocero, M. J. (2012). Assisted extraction of Rosemary antioxidants with green solvents. Journal of Food Engineering, 109(1), 98-103. http://dx.doi.org/10.1016/j. jfoodeng.2011.09.029.

Scalzo, J., Politi, A., Pellegrini, N., Mezzetti, B., \& Battino, M. (2005). Plant genotype affects total antioxidant capacity and phenolic contents in fruit. Nutrition, 21(2), 207-213. PMid:15723750. http:// dx.doi.org/10.1016/j.nut.2004.03.025.

Selani, M. M., Contreras-Castillo, C. J., Shirahigue, L. D., Gallo, C. R., Plata-Oviedo, M., \& Montes-Villanueva, N. D. (2011). Wine industry residues extracts as natural antioxidants in raw and cooked chicken meat during frozen storage. Meat Science, 88(3), 397-403. PMid:21342750. http://dx.doi.org/10.1016/j.meatsci.2011.01.017.

Shahidi, F., \& Zhong, Y. (2010). Novel antioxidants in food quality preservation and health promotion. European Journal of Lipid Science and Technology, 112(9), 930-940. http://dx.doi.org/10.1002/ ejlt.201000044.

Singleton, V. L., Orthofer, R., \& Lamuela-Raventós, R. M. (1999). Analysis of total phenols and other oxidation substrates and antioxidants by means of Folin-Ciocalteau reagent. Methods in Enzymology, 299, 152-178. http://dx.doi.org/10.1016/S0076-6879(99)99017-1.

Teruel, M. R., Garrido, M. D., Espinosa, M. C., \& Linares, M. B. (2015). Effect of different format-solvent Rosemary extracts (Rosmarinus officinalis) on frozen chicken nuggets quality. Food Chemistry, 172(1), 40-46. PMid:25442521. http://dx.doi.org/10.1016/j. foodchem.2014.09.018.

Wojdylo, A., Oszmianski, J., \& Czemerys, R. (2007). Antioxidant activity and phenolic compounds in 32 selected herbs. Journal of Food Chemistry, 105(3), 940-949. http://dx.doi.org/10.1016/j. foodchem.2007.04.038.

Zhang, L., Lin, Y. H., Leng, X. J., Huang, M., \& Zhou, G. H. (2013). Effect of sage (Salvia officinalis) on the oxidative stability of Chinese-style sausage during refrigerated storage. Meat Science, 95(2), 145-150. PMid:23739264. http://dx.doi.org/10.1016/j.meatsci.2013.05.005.

Zheng, W., \& Wang, S. Y. (2001). Antioxidant activity and phenolic compounds in selected herbs. Journal of Agricultural and Food Chemistry, 49(11), 5165-5170. PMid:11714298. http://dx.doi. org/10.1021/jf010697n. 